\title{
Environmental assessment of atmospheric dioxin dispersion from a Municipal Wastes Power Plant (MWPP), Indonesia
}

Dian Purwitasari Dewantia ${ }^{\mathrm{a}}$ Albertus Sulaiman ${ }^{\mathrm{b}}$

${ }^{a}$ Pusat Teknologi Lingkungan, Badan Pengkajian dan Penerapan Teknologi (BPPT), Kawasan Puspiptek Serpong, Indonesia

${ }^{\mathrm{b}}$ Research Center for Physics, Indonesian Insitute of Sciences (LIPI), Kawasan Puspiptek Serpong, Indonesia [+62 21-7560556]

\section{Article Info:}

Received: 14 - 10 - 2020

Accepted: 16 - 03 - 2021

Keywords:

Atmospheric dispersion, dioxin, environmental assessment, waste incinerator

\section{Corresponding Author:}

Albertus Sulaiman

Research Center for Physics, Indonesian Institute of Sciences (LIPI);

Tel. +62-21-7560556

Email:

albertus.sulaiman@lipi.go.id; asulaiman1970@gmail.com

\begin{abstract}
We assess the environmental effect of the dioxin dispersion from the municipal waste power plant (MWPP) covering, characteristics of the dispersion, and health risk in Indonesia. The dispersion studies through modelling which is done with the following steps: 1) estimate dioxin emissions from incinerator processing, 2) design the dioxin dispersion by literature review, 3) calculate health risk of communities based on the dispersion modelling. The results show that the dispersion of dioxin is represented in the form of a non-Gaussian solution of the advectiondiffusion equation with taking into account the settling and deposition velocity. In the case of MWPP with capacity, 80 tonnes per day produce a concentration of $0.04 \mathrm{pg} T E Q / \mathrm{Nm} 3$ in residential areas, which are located $200 \mathrm{~m}$ from a chimney. Inhalation exposure resulting is $5.28 \mathrm{pg} 1-T E Q /(\mathrm{kg}$ day) to adults and $6.95 \mathrm{pg} \mathrm{1-TEQ/(kg-day)} \mathrm{to} \mathrm{children.} \mathrm{The} \mathrm{strategy} \mathrm{took} \mathrm{to}$ adjust by WHO environmental quality standard 4 pg 1 -TEQ /(kg-day), we increase the reduction of Air Pollution Control (APC) 25\%. The calculation of emissions based on combustion processes shows that the dioxin concentration of MWPP is still below the WHO's threshold.
\end{abstract}

How to cite (CSE Style $8^{\text {th }}$ Edition):

Dewanti DP, Sulaiman A. 2021. Environmental assessment of atmospheric dioxin dispersion from a Municipal Wastes Power Plant (MWPP), Indonesia. JPSL 11(1): 57-68. http://dx.doi.org/10.29244/jpsl.11.1.57-68.

\section{INTRODUCTION}

In the last few decades, it has been realized that the burning of plastic produces pollutants that are called dioxin (Hoogenboom et al., 1995). Dioxins also called polychlorinated dibenzo-para-dioxins (PCDDs), are chemical compounds consisting of two benzene rings connected with oxygen $(\mathrm{O})$ atoms which are formed due to by-products from incomplete combustion or other chemical processes (when chlorine, carbon, hydrogen, and oxygen are together in hot conditions) and often occur at temperatures of $400-640^{\circ} \mathrm{C}$ (Lali, 2018). Today the source of dioxin comes mainly from human activities (anthropogenic), namely large-scale industry and the use of chemical chlorine, combustion (incineration of domestic waste, sludge waste, medical waste, and hazardous waste), combustion of various fuels such as coal, wood, and products petroleum products, as well as high-temperature sources such as cement kilns, and uncontrolled combustion (Mc Kay, 2002). Chlorine is the principal reactant for the formation of dioxin. For example, the municipal waste contains $0.5-1 \%$ chlorine mass of the total waste mass (Lali, 2018; USEPA, 1999). 
It is intensifying the infrastructure development of MWPP in 12 cities in Indonesia. To produce electricity, municipal waste must be burned at a minimum temperature of $850^{\circ} \mathrm{C}$ to produce superheated in the boiler to drive the turbine (Winanti, 2018). Burning municipal waste, which contains a lot of plastic, will produce dioxins. But the residence time of the combustion gas is designed to be a minimum of 2 seconds in the chamber burning thus dioxins can be destroyed. In the operational MWPP, we cannot guarantee that this condition always occurs. In fact, not all MWPP is safe from dioxin emissions, especially when starting up and shutting down the engine with a greater concentration during stable conditions. An example, the dioxin dispersion from Hangzhou MWPP with a capacity of 800 tons per day give air concentration around 0.39 $\mathrm{pg} / \mathrm{Nm}^{3}$ at a distance of about $100 \mathrm{~m}$ from the chimney higher than WHO requirements $0.11 \mathrm{pg} \mathrm{TEQ} / \mathrm{Nm}^{3}$ (toxic equivalent pentagrams per standard cubic meter) (Ma et al., 2012). In some European countries, the use of MWPP has met WHO standards. Measurements of dioxin concentrations in soils, vegetation and air around the Portugal Catalonia MWPP showed concentrations of $0.06 \mathrm{ng}$ I-TEQ kg-1, $0.58 \mathrm{ng}$ I-TEC kg-1, and $0.01 \mathrm{pg} / \mathrm{Nm}^{3}$, respectively (Vilavert et al., 2012). The ambient dioxin concentration of 85 large and 39 small MWPP in France showed MSWI is operated well below the EU and French standard of $0.1 \mathrm{pg} / \mathrm{Nm}^{3}$ (Nzihou et al., 2012).

Due to dioxins being solid in form with a density slightly higher than $\mathrm{NO}_{2}$, the Gaussian dispersion model commonly used to describe the distribution of pollutants is not appropriate. The measurement results in industrial and urban areas in Taiwan show a linear relationship between $\mathrm{PM}_{10}$ (particles with a density of 2 $\mathrm{g} / \mathrm{cm}^{3}$ ) with dioxin concentration that is $y=0.0052 x-0.021$ with $R^{2}=0.998$ where $x$ is the concentration of $\mathrm{PM}_{10}$ and $y$ is the concentration of dioxin (Chandra et al., 2015, Lee et al., 2016). When away from the chimney, dioxin is not in the gas phase but in the particulate phase, which has a settling and deposition velocity (Lohman and Seigneur, 2001). The dioxin dispersion model used is based on the Gaussian model, which does not consider the settling and deposition rates. For example, the calculation of the Gaussian model of iron and non-iron smelting plants in the Cilegon industrial area with an activity of around 2 million tons per year or $6.3 \mathrm{~kg} / \mathrm{s}$ produces dioxins of $150000 \mathrm{pg} \mathrm{TEQ} / \mathrm{m}^{3}$ at a distance of $10 \mathrm{~km}$ (Warlina et al., 2008). Furthermore, emissions of $96165 \mathrm{pg} \mathrm{TEQ} / \mathrm{m}^{3}$ will produce an ambient concentration of $0.73 \mathrm{pg} \mathrm{TEQ} / \mathrm{m}^{3}$ (Warlina et al., 2008, Warlina, 2015). This value far exceeds the WHO threshold of $0.11 \mathrm{pg} \mathrm{TEQ} / \mathrm{m}^{3}$ in 1990 and changed to $0.023 \mathrm{pg} \mathrm{TEQ} / \mathrm{Nm}^{3}$ starting in 1999 (Ma et al., 2012). As a comparison, the measurement of ambient air in an industrial area in Taiwan has an ambient air concentration of $0.043-0.053 \mathrm{pg} / \mathrm{Nm}^{3}$ (Lee et al., 2016).

What is the most appropriate model for describing the dispersion of dioxin in the atmosphere? How can we determine the health risks of the community in affected areas? This question will be answered in this paper. This paper develops the calculation method (modelling) of atmospheric dioxin dispersion from municipal waste power plant activities. Because there is no measurement of dioxin concentration in the Indonesian atmosphere, the model validation will be done by comparing the results of the model with the observation that has been made in other countries by including the model factors as close as possible to the existing conditions.

\section{METHODOLOGY}

In this chapter, we show step by step the modelling of atmospheric dispersion of dioxin for environmental impact studies. Because there is no primary data from laboratory analysis of dioxin concentrations in both chimney emissions and ambient air, we use secondary data obtained from the literature. The combustion process is obtained from a waste incinerator. The explanation is as follows. 


\section{The Concept of Atmospheric Dispersion of Dioxin}

The dispersion of dioxins in the atmosphere behaves differently than other pollutants. Physically dioxin has a small density of $1.8 \mathrm{~g} / \mathrm{cm}^{3}$ while $\mathrm{NO}_{2}$ gas is $1.45 \mathrm{~g} / \mathrm{cm}^{3}$ and $\mathrm{SO}_{2}$ is $2.63 \times 10^{-3} \mathrm{~g} / \mathrm{cm}^{3}$ but dioxin can be classified in non-gas particles. Dioxin is chemically classified as inactive (non-decay) and undergoes dry deposition (particles that fall to the ground) at a speed of about $0.2-0.5 \mathrm{~cm} / \mathrm{s}$ in Greece (Olie et al., 1977), 0.27-0.28 (coastal), 0.19-0.24 (mountain), 0.148-0.162 (industrial estate), 0.49-0.98 (urban) in Taiwan (Chandra et al., 2015, Lee et al., 2016, Zhu et al., 2017). For dioxins in the atmosphere, dry deposition is more dominant than wet deposition (Wu et al., 2009, Huang et al., 2011, Chandra et al., 2015, Lee et al., 2016).

The ambient air samples' measurements around municipal solid waste incinerators (MSWI) ranging from near the chimney mouth to away from the chimney mouth show the dioxin close to chimney behaves as a gas phase and far from the chimney gradually behave into particles through the absorption process. Dioxin will be bound by particulates so that it will be deposited to the soil surface following the deposition behavior of dust particles (Chao et al., 2004, Chandra et al., 2015). When dioxin is in the gas phase, the deposition will not occur because there is a balance between buoyancy and gravity so that the gas phase will always float in the atmosphere (Ryan, 1993; Mohan, 2016). Based on the above conditions, the dioxin dispersion generated by a chimney can be constructed in Figure 1.

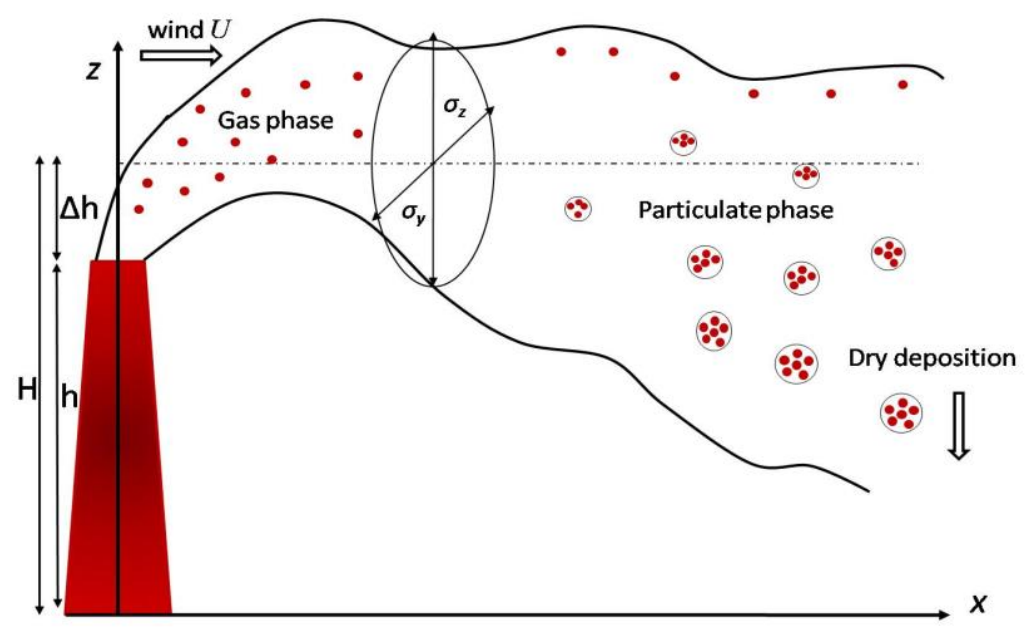

Figure 1 The dioxin dispersion coordinate system of a chimney (the red dot represents Dioxin), $h$ is the height of the chimney, $\Delta h$ is the height of the plume rise, and $\sigma(y, z)$ is the dispersion coefficient

\section{The Emission and Plume Rise}

Because dioxin is a hazardous substance, activities must be treated in a chimney wherein it is categorized based on the ability to absorb dioxin. Emission factors are determined based on the chimney's treatment known as the Air Pollution Control (APC) which has four classes. Emissions= Production Capacity $\times$ Emission Factors, where the emission factors are represented as follows, Sophisticated APC has emission factors $0.5 \mu \mathrm{g}$ TEQ/ton, Good APC $300.5 \mu \mathrm{g}$ TEQ/ton, minimum APC $359 \mu \mathrm{g}$ TEQ/ton and non APC has emission factors $3500 \mu \mathrm{g}$ TEQ/ton (Fiani et al., 2013). The calculation of pollutant emissions from the combustion process can be calculated based on the mass or volume of flue gas from combustion. Flue gas is a product of the combustion reaction of several components contained in the burned waste. Flue gas is calculated based on component combustion reactions obtained from the ultimate analysis of waste consisting of moisture $\left(\mathrm{H}_{2} \mathrm{O}\right)$, carbon, hydrogen, sulfur, oxygen, nitrogen, and ash (Lee and Lin, 2007; Nzihou et al., 2012). The unit of waste component is converted to moles and calculated the product formed in 
stoichiometry will produce a total mass of product flue gas as much as $\mathrm{n} \mathrm{kg}$ of $\mathrm{N} \mathrm{kg}$ of municipal waste that is burned.

The smoke that is emitted by the factory chimney depends on the initial burst velocity $\left(V_{a}\right)$, the height of the chimney $\left(H_{0}\right)$ and the temperature $\left(T_{a}\right)$, and the diameter of the chimney $(d)$, which can gush up and reach a height of more than ten times the height of the chimney. From the comparison of the data and the model, we recommend the Moses and Carson model for plume rise as follows (Carson and Moses, 1969).

$$
\Delta h=\frac{V_{s} d}{U}\left(1.5+2.68 \times 10^{3} P d\left(\frac{T_{s}-T_{a}}{T_{a}}\right)\right)
$$

Where $U$ is downwind velocity, $P$ is atmospheric pressure in the chimney, $V_{s}$ is speed of smoke coming out of the chimney, $T_{s}$ is gas temperature coming out of the chimney.

\section{Mathematical Model of Atmospheric Dispersion of Dioxin}

Modelling the dispersion of pollutants in the atmosphere is nothing else the problem solving of conservation of mass from a pollutant that disperses in the atmosphere. Because dioxin is a non-reactive pollutant, the source term or sink will be zero. Based on the dioxin dispersion construction as stated in Figure 1 , we use a local scale model. For the local scale model, there are two basic phenomena, namely the dominant advection condition (strong winds), so that dispersion in the direction of the wind (downwind) can be ignored $(U \sim 0)$. The second model is a weak wind condition so that the directional dispersion of the wind cannot be ignored.

\section{High Wind Velocity Model}

We solve steady state advection diffusion equation with settling velocity taken into account and by assumption as follow, the wind speed is constant and dominant in one direction, the source of pollutants is determined at a point with height $H=h+\Delta h$ with $h$ the height of a chimney, and $\Delta h$ is the immediate puff (boasting up) that depends on buoyancy. The boundary conditions are $\kappa \partial C / \partial x=0, \partial C / \partial z=0$ and $C(x, y, z \rightarrow$ $\infty)=0$. This yields the dioxin dispersion have an analytical solution as (Stockie, 2011; Ma et al., 2012).

$$
C(x, y, z)=\frac{Q}{2 \pi U \sigma_{y} \sigma_{z}} \exp \left(-\frac{y^{2}}{2 \sigma_{y}^{2}}\right) \times \Psi(x, z)
$$

where

$$
\begin{aligned}
\Psi(x, z)= & \exp \left(-\frac{W_{s}(z-H)}{2 \kappa_{z}}-\frac{W_{s}^{2} \sigma_{z}^{2}}{4 \kappa_{z}^{2}}\right) \times\left[\exp \left(-\frac{(z-H)^{2}}{2 \sigma_{z}^{2}}\right)+\exp \left(-\frac{(z+H)^{2}}{2 \sigma_{z}^{2}}\right)-\frac{W_{0} \sqrt{2 \pi} \sigma_{z}}{\kappa_{z}}\right. \\
& \left.\times \exp \left(\frac{W_{0}(z+H)}{\kappa_{z}}+\frac{W_{0}^{2}}{\sqrt{2} \sigma_{z}}\right) \operatorname{erfc}\left(\frac{W_{0} \sigma_{z}}{\sqrt{2} \kappa_{z}}+\frac{(z+H)}{\sqrt{2} \sigma_{z}}\right)\right]
\end{aligned}
$$

Where $Q$ is discharge rate $(\mathrm{kg} / \mathrm{det}), \sigma_{y, z}$ is dispersion coefficient, $\kappa$ is zonal difusivity coefficient, $H$ is initial emission height, $(x, y, z)$ are zonal, meridional and vertical coordinate system. $W_{0}=W_{d}-0.5 W_{s}, \kappa_{z}=0.5 U$ $\left.d \sigma_{z} / d x, \quad r_{(y, z)}=\sigma_{(y, z)}\right)^{2} / 2$, erfc is a complementary error function. The dioxin unit's unit of concentration commonly used is a nanogram $n g / \mathrm{Nm}^{3}\left(1 \mathrm{ng}=10^{-9} \mathrm{~g}\right)$ or $\mathrm{pg} / \mathrm{Nm}^{3}\left(1 \mathrm{pg}=10^{-12} \mathrm{~g}\right)$. $\mathrm{N}$ means normal where the gas is measured under normal conditions, for EPA-USA normal is a gas at the temperature $25^{\circ} \mathrm{C}$ and the pressure $101.325 \mathrm{kPa}$. This paper will follow the EPA-USA rules where the dioxin unit is measured in $\mathrm{pg} / \mathrm{Nm}^{3}$. 
Based on the linear relationship between $\mathrm{PM}_{10}$ and dioxin concentration [Chandra et al., 2015; Lee et al., 2016] we use the settling velocity and dry deposition $\mathrm{PM}_{10}$ (a particle with diameter $\leq 10 \times 10^{-6} \mathrm{~m}$ ) i.e. the settling velocity of $2.9 \mathrm{~mm} / \mathrm{s}$ and the dry deposition speed of $5.2 \mathrm{~mm} / \mathrm{s}$ (Okubo and Kuwahara, 2019) The relation between the coefficient of dispersion in the zonal wind direction is given by,

$$
\sigma_{y}^{2}(x)=\frac{2}{u} \int_{0}^{x} \kappa_{y}(\eta) d \eta \quad ; \quad \sigma_{z}^{2}(x)=\frac{2}{u} \int_{0}^{x} \kappa_{z}(\eta) d \eta
$$

The coefficient of dispersion or standard deviation $\sigma_{(y, z)}$ depends on the stability of the atmosphere which has a general form $\sigma_{(y, z)}=a_{(y, z)} x^{b(y, z)}$ with $x>0$ (Seinfield and Pandis, 2016). For an atmospheric scale of less than $5 \mathrm{~km}$, the coefficient is represented in a table called the Briggs sigma table (Briggs, 1973). Generally, in Indonesia, the atmospheric conditions are convective then we use $a_{y}=0.34, b_{y}=0.82, a_{z}=0.75$ dan $b_{z}=0.82$. Equation 2 states that the wind direction is parallel to the $\mathrm{x}$-axis. If the wind direction has an angle $\theta$ relative to the $\mathrm{x}$-axis then the coordinate transformation is performed as follows, $x \rightarrow x^{\prime}=x \cos (90$ $\theta)+y \sin \left(90-\theta, y \rightarrow y^{\prime}=-x \sin (90-\theta)+y \cos (90-\theta)\right.$, thus dioxin dispersion is obtained for arbitrary wind direction, according to wind rose data (Sulaiman and Sadly, 2014).

\section{Low Wind Velocity Model}

Whereas for winds smaller than $1.5 \mathrm{~ms}^{-1}$, the dioxin dispersion in parallel to the wind ( $x$-direction) is significant enough so that the zonal $U$ velocity and the dispersion coefficient $\left(\kappa_{x}\right)$ in the zonal direction cannot be neglected. Analytical solutions based on the Fourier analysis method and by taking into account the deposition rate yields,

$$
C(x, y, z)=\int_{0}^{\infty} \frac{Q}{4 \pi \sqrt{2 \pi} \sigma_{x} \sigma_{y} \sigma_{z}} e^{-\frac{(x-U t)^{2}}{2 \sigma_{x}^{2}}} d t \times \exp \left(-\frac{y^{2}}{2 \sigma_{y}^{2}}\right) \times \Psi(x, z)
$$

Thus Equation 2 and Equation 4 represent dioxin's dispersion in the local-scale atmosphere by considering synoptic wind speeds. The integrals in Equation 4 can be solved by a Gaussian integral $\int_{(-\infty, \infty)} \exp (-$ $\left.a x^{2}+b x+c\right) d x=\sqrt{ }(\pi / a) \exp \left[\left(b^{2} / 4 a\right)+c\right]$.

\section{Health Risk due to Dioxin Exposure}

In this paper, the health risks of dioxin exposure will be calculated based on the Nouwen equation. This risk is measured by dioxin exposure per day per person (adults and children). The formulation is given as follows (Nouwen et al., 2001).

$$
I N H=\frac{V_{r} \times C_{a t m} \times f_{r} \times t_{r}}{B W}
$$

Where $I N H$ is daily dioxin exposure level ( $\mathrm{ng} I-T E Q /\left(\mathrm{kg}\right.$-day)), $V_{r}$ is average ventilation $\left(20 \mathrm{~m}^{3} / \mathrm{d}\right.$ for adults and $7.6 \mathrm{~m}^{3} / \mathrm{d}$ for children), $C_{a t m}$ is dioxin concentration in the air $\left(p g T E Q / \mathrm{Nm}^{3}\right), f_{r}$ is alveolar fraction in the throat ( 0.75 adults/children), $t_{f}$ is fraction time ( 0.616 adults and 0.457 children) and $B W$ is weight (in this case we make an average of $70 \mathrm{~kg}$ adults and $15 \mathrm{~kg}$ children). This formula is known as inhalation exposure which is caused by emissions from a factory with the assumption every individual is exposed 24 hours per day with the same concentration both inside and outside the home.

\section{RESULT AND DISCUSSION}

We review the case of MWPP in Bantargebang, Indonesia (Thohiroh and Mardiati, 2017). MWPP has a chimney with a height of $H_{0}=30 \mathrm{~m}$, gas flow velocity in the chimney mouth $V_{s}=3.17 \mathrm{~m} / \mathrm{s}$, chimney diameter $0.38 \mathrm{~cm}$, atmospheric pressure $\mathrm{P}=1000 \mathrm{~Pa}$, the temperature in the mouth of the chimney $T_{s}=623 \mathrm{~K}$ and 
ambient air temperature at $T_{u}=300 \mathrm{~K}$. MWPP has an activity that is stated by the production capacity of 80 tons/day, the resulting emissions based on the calculation of emission factor are $40 \mu \mathrm{g} T E Q /$ day for Sophisticated APC, $2400 \mu \mathrm{g} T E Q /$ day for Good APC, $28 \times 10^{3} \mu \mathrm{g}$ TEQ/day for minimal APC and $28 \times 10^{4} \mu \mathrm{g}$ $T E Q /$ day for non-APC. In contrast, the calculation of emissions based on the combustion process is more complicated by sorting the waste composition. We calculate the concentration of $\mathrm{C}, \mathrm{H}, \mathrm{O}, \mathrm{N}, \mathrm{S}$, and ash from each component to determine the total $\mathrm{C}, \mathrm{H}, \mathrm{O}, \mathrm{N}, \mathrm{S}$, and ash from the waste. For example, it is assumed that the total amount of $100 \mathrm{~kg}$ of waste with organic waste has a moisture content (MC) of $70 \%$, then the dry weight of organic waste is $53.7501-(0.7) \times(53.7501)=16.12503 \mathrm{~kg}$. From the dry weight will be obtained the amount of $\mathrm{C}$ organic waste $0.48 \times 16.12503=7.74 \mathrm{~kg}, \mathrm{H}=1.03 \mathrm{~kg}, \mathrm{O}=6.06 \mathrm{~kg}, \mathrm{~N}=0.41 \mathrm{~kg}, \mathrm{~S}=0.06 \mathrm{~kg}$, Ash= $0.81 \mathrm{~kg}$, and $\mathrm{H}_{2} \mathrm{O}=37.63 \mathrm{~kg}$. The calculation shows that the results of the ultimate analysis consisted of carbon $26.19 \mathrm{~kg}$, hydrogen $3.35 \mathrm{~kg}$, oxygen $16.29 \mathrm{~kg}$, nitrogen $0.57 \mathrm{~kg}$, sulfur $0.1 \mathrm{~kg}$, water $38.95 \mathrm{~kg}$, and ash $13.97 \mathrm{~kg}$ burned using air which has a composition of $0.05 \% \mathrm{CO}_{2}, \mathrm{~N}_{2} 76.10 \%, \mathrm{O}_{2} 23.06 \%, \mathrm{H}_{2} \mathrm{O} 0.79 \%$ with excess $80 \%$ at a combustion temperature of $900^{\circ} \mathrm{C}$. The unit of waste component is converted into mol (n) where $\mathrm{n}$ is the mass $(\mathrm{m})$ divided by the molecular weight $(\mathrm{BM})$ then the product formed in stoichiometry is calculated. It yields a total mass of product flue gas of $210614 \mathrm{~kg}$ from $100 \mathrm{~kg}$ of waste burned.

The combustion reaction showed the $\mathrm{O}_{2}$ requirement to burn $100 \mathrm{~kg}$ of waste is $107264 \mathrm{~kg}$, so that the total air needed with excess oxygen $80 \%$ is $837.14 \mathrm{~kg}$. Previous studies conducted by (Ujam and Eboh, 2012) take $8.66 \mathrm{~kg}$ of air to burn $1 \mathrm{~kg}$ of trash with excess oxygen by $80 \%$. If the waste incinerator can process waste up to 80 tons per day, the flue gas will produce $976016 \mathrm{~m}^{3}\left(220^{\circ} \mathrm{C}\right)$ per day. These calculation results are the same as calculations made by (De Vivo et al., 2017). The dioxin emissions in the volume of flue gas production are $1.48 \times 10^{-5} \mu \mathrm{g} T E Q / \mathrm{s}$ for Sophisticated APC, $1.48 \times 10^{-3} \mu \mathrm{g} T E Q / \mathrm{s}$ for Good APC, $1.03 \times 10^{-2} \mu \mathrm{g} T E Q / s$ for minimal APC, and $1.03 \mu \mathrm{g} T E Q / \mathrm{s}$ for non-APC. Calculations with emission factors have a higher value of two orders. For example, the sophisticated APC with emission factors having a $40 \mu \mathrm{g}$ $\mathrm{TEQ} /$ day value while calculations with the combustion process produce emissions of $0.013 \mu \mathrm{g} \mathrm{TEQ} / \mathrm{day}$. Thus, the measure with emission factors has a high enough error. For studies with worst-case scenarios, the emission factors method is acceptable.

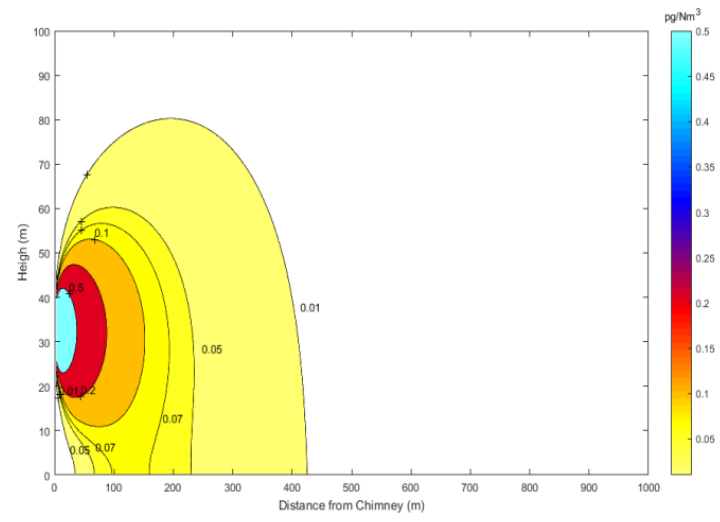

a)

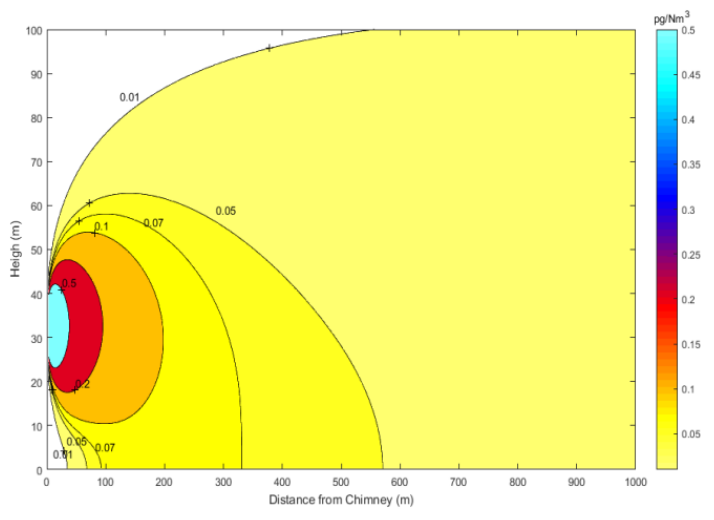

b)

Figure 2 Dispersion of dioxins in the vertical direction with emission sources for sophisticated APC conditions and chimney height of $30 \mathrm{~m}$ and wind speeds of $2.5 \mathrm{~m} / \mathrm{s}$ where a) Solution of Equation 4 and b)

Gaussian Solution $\left(w_{d}=w_{s}=0\right.$ in Equation 4$)$

First, we simulate dioxin dispersion in the $(x-z)$ direction to see the dioxin dispersion's vertical behaviors and compare it to the Gaussian model. In this simulation, we use the wind in October that blows to the southeast at a speed of $2.5 \mathrm{~m} / \mathrm{s}$. The winds head to the residential area so that the possibility of the settlement is quite large. With a velocity of $2.5 \mathrm{~m} / \mathrm{s}$, the dispersion will meet Equation 2 with type-C stability 62 
conditions. Dioxin dispersion in the vertical direction is depicted in Figure 2a. In MWPP conditions equipped with water pollution control with a sophisticated scenario, then at a distance of $30-230 \mathrm{~m}$ from the chimney will be exposed to $0.05 \mathrm{pg} / \mathrm{Nm}^{3}$ dioxin. While at a distance between $100-170 \mathrm{~m}$ will be exposed to dioxin by $0.07 \mathrm{pg} / \mathrm{Nm}^{3}$. Exposure concentrations of $0.1 \mathrm{pg} / \mathrm{Nm}^{3}$ are only at elevations above $10 \mathrm{~m}$ and disperse as far as $150 \mathrm{~m}$. If using the Gaussian model (Figure 2b), dioxin will spread to a wider area. For example, dioxin with a concentration of $0.05 \mathrm{pg} / \mathrm{Nm}^{3}$ will disperse as far as $80 \mathrm{~m}$ to $580 \mathrm{~m}$. The concentration of $0.01 \mathrm{pg} / \mathrm{Nm}^{3}$, disperse over an area of more than $1 \mathrm{~km}$ and altitudes more than $100 \mathrm{~m}$. The Gaussian model is suitable for dispersing gaseous pollutants (Alimuddin et al., 2018; Dewi et al., 2018; Assegaf, 2018). Measurement of ambient air in an industrial area in Taiwan has an ambient air concentration of 0.043-0.053 pg/ $\mathrm{Nm}^{3}$ (Lee et al., 2016), whereas, for urban areas, it has an ambient air concentration of 0.0039-0.0136 pg/ $\mathrm{Nm}^{3}$ (Chandra et al., 2015). Quality standards for ambient air quality according to WHO around $0.11 \mathrm{pg} / \mathrm{Nm}^{3}$ in 1990. Conditions with the assumption of sophisticated APC will produce dioxin concentrations that are still below WHO quality standards.

Some countries have measured ambient air concentrations for dioxin, for example in China had ambient air concentrations of $0.19 \mathrm{pg} \mathrm{TEQ} / \mathrm{m}^{3}$ before the presence of MSW incinerators and 0.495 to $3.03 \mathrm{pg} \mathrm{TEQ} / \mathrm{m}^{3}$ with the presence of MSW Incinerators (Xu et al., 2009). Modelling studies of dioxin dispersion with Gaussian models from the MSW plant with a capacity of 800 tons/day provide ambient concentrations of around $0.04 \mathrm{pg} \mathrm{TEQ} / \mathrm{m}^{3}$ at distances of $800 \mathrm{~m}$ for wind speeds below $1.5 \mathrm{~m} / \mathrm{s}$ and $0.05 \mathrm{pg} \mathrm{TEQ} / \mathrm{m}^{3}$ at distances of $1 \mathrm{~km}$ for wind speeds of more than $1.5 \mathrm{~m} / \mathrm{s}$ (Ma et al., 2012). If we calculate with Equation 2 and Equation 4 produce a concentration of $0.005 \mathrm{pg} \mathrm{TEQ} / \mathrm{Nm}^{3}$ at a distance of $800 \mathrm{~m}$ for wind conditions below $1.5 \mathrm{~m} / \mathrm{s}$ and $0.001 \mathrm{pg} \mathrm{TEQ} / \mathrm{Nm}^{3}$ for wind conditions above $1.5 \mathrm{~m} / \mathrm{s}$. These results are consistent with the study in this paper, where the Gaussian model provides over-estimated results.
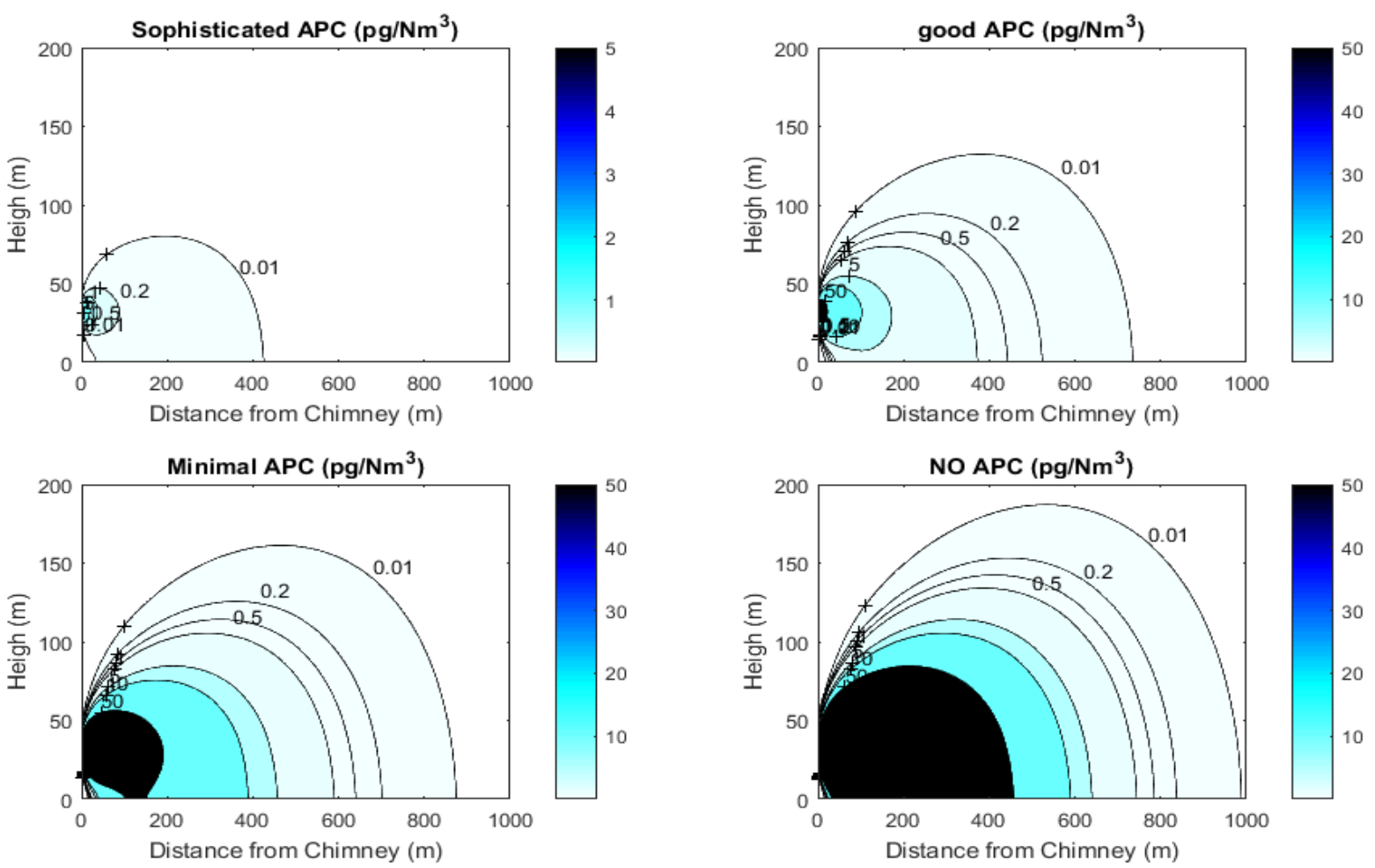

Figure 3 Dispersion of dioxin in the vertical direction with emission sources for the four conditions of the APCS (Air Pollution Control Strategy) scenario and chimney height of $30 \mathrm{~m}$ and wind speed of $2.5 \mathrm{~m} / \mathrm{s}$ 
In the same way, the simulations for the four APC scenarios are depicted in Figure 3. APC is a system that must exist in a process that involves combustion that functions to control dioxin residues. The APC system used in a factory depends on the type of incinerator and residual cleaning equipment installed. Incinerators involving dioxin have two types, namely dry (semi-dry) systems, and wet systems. Both types can minimize the release of dioxin into the atmosphere (Astrup, 2008). Sophisticated APS usually uses semidry lime scrubbing and filter bags equipped with activated carbon injection. This is an important series of preventing and minimizing dioxin emissions through the chimney. Figure 3 shows that in the sophisticated APC, the dioxin concentration was $0.01 \mathrm{pg} / \mathrm{Nm}^{3}$ which is still included in the safe category (Abad et al., 2006). In this condition, we see no concentration of $0.2 \mathrm{pg} / \mathrm{Mm} 3$ below $10 \mathrm{~m}$ height (the height of houses in settlements is less than $10 \mathrm{~m}$ ) so that the general public is not exposed to dioxin. For the cases without APC, produce dioxin concentrations at ground level, above $50 \mathrm{pg} / \mathrm{Nm}^{3}$ at a distance of $50 \mathrm{~m}$ to $500 \mathrm{~m}$ from the MWPP chimney. While the area between $50 \mathrm{~m}$ to more than $800 \mathrm{~m}$ and altitude reaches $150 \mathrm{~m}$, have concentrations above the WHO quality standard. The minimum APC, the area above the quality standard in the distance of $50 \mathrm{~m}$ to $700 \mathrm{~m}$. The minimum condition of the APC with concentrations above $50 \mathrm{pg} / \mathrm{Nm}^{3}$ occur between $100 \mathrm{~m}$ to $150 \mathrm{~m}$ from the MWPP chimney. The APC good scenario has an area exceeding the quality standard between $40 \mathrm{~m}$ to $500 \mathrm{~m}$. The sophisticated APC is a must for getting dioxin exposure below the WHO quality standard from the above results.

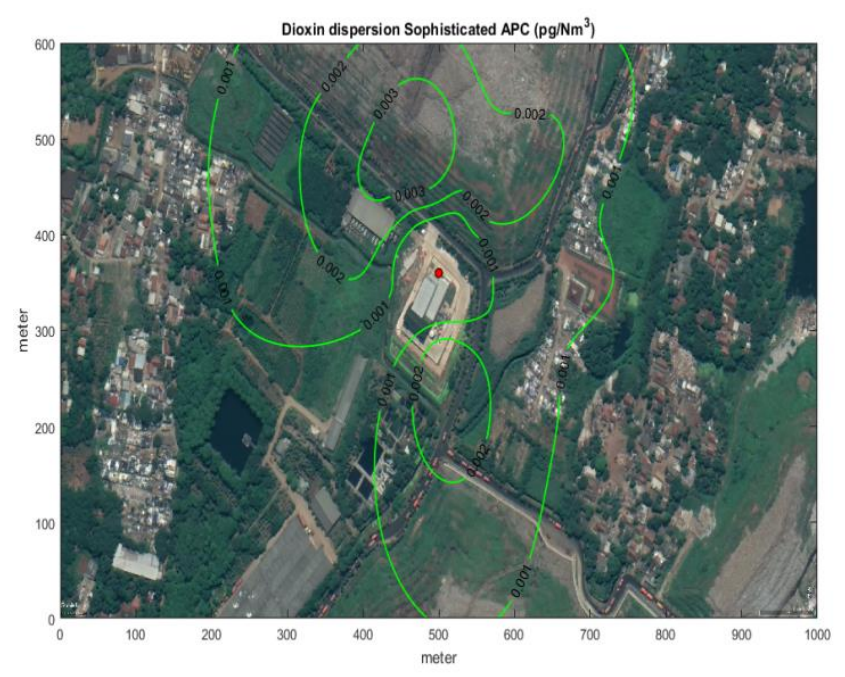

a)

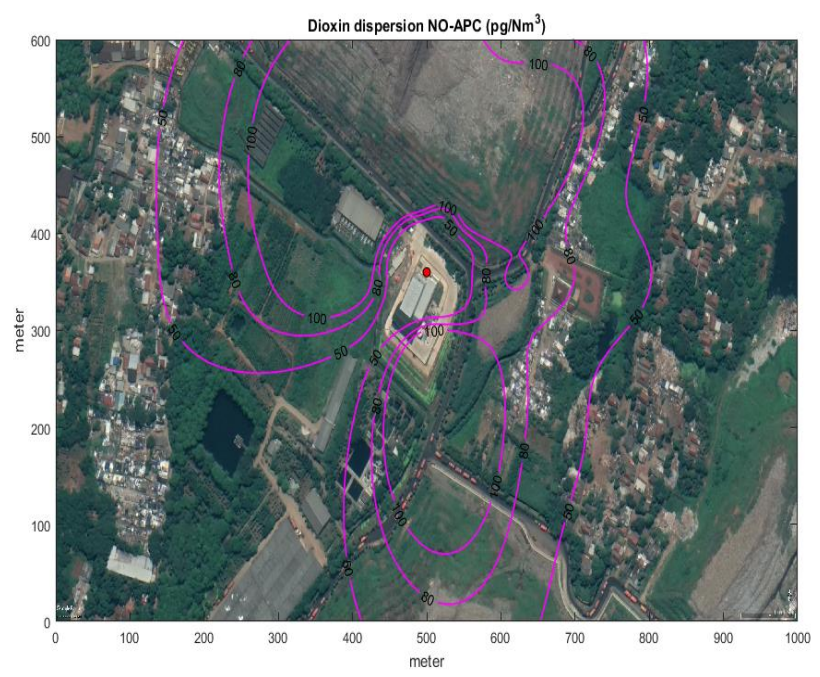

b)

Figure 4 Isopleths from the dioxin distribution in the horizontal direction of the MWPP Bekasi where emissions are calculated based on the combustion process, for the accumulation of one year with average monthly wind a) sophisticated APC, b) do not use APC

The calculation of emissions based on the combustion process produces a significant change where scenarios with sophisticated APC and without APC are depicted in Figure 4a and Figure 4b, respectively. With the presence of APC, the ambient dioxin concentration becomes $0.001 \mathrm{pg}$ TEQ/ $/ \mathrm{Nm}^{3}$ at the residential location. Whereas the condition without APC will produce a concentration of around $50 \mathrm{pg} \mathrm{TEQ} / \mathrm{Nm}^{3}$. Calculation of emissions based on combustion processes has a much smaller ambient concentration than analyses using emission factors in order $10^{-1}$ or about ten times less. For studies that prioritize the worst-case scenario, then the calculation with emission factors is recommended, but in case of a favorable scenario, the calculation by using the combustion process is recommended. 
Health risks from exposure to dioxin can be identified by looking at the exposed area is around 100 houses. Assuming that in one house, there are two adults and two children, there are 200 exposed adults and 200 exposed children. Each person has a risk of exposure to dioxin calculated based on Equation 5 as follows, $I N H_{\text {adults }}=20 \times 0.04 \times 0.75 \times 0.616 / 70=0.00528 \mathrm{ng} \mathrm{I-TEQ} /(\mathrm{kg}-$ day $)=5.28 \mathrm{pg} \mathrm{I-TEQ} /(\mathrm{kg}-$ day $)$ and $I N H_{\text {children }}=7.6 \times 0.04 \times 0.75 \times 0.457 / 15=0.00695 \mathrm{ng} \mathrm{I}-\mathrm{TEQ} /(\mathrm{kg}$-day) or $6.95 \mathrm{pg} \mathrm{I-TEQ} /(\mathrm{kg}$-day). WHO issued a dioxin exposure threshold of $10 \mathrm{pg} \mathrm{I}-\mathrm{TEQ} /(\mathrm{kg}$-day) for all sources of exposure to dioxin (not just inhalation) (Hoogenboom et al., 2001; WHO, 2000). This condition is indeed still below the WHO threshold. But we should remark that dioxin exposure not only comes from inhalation but also from vegetation, soil, water, food, and animals at the location of the activity. For example, chicken eggs in the MWPP have a high possibility be exposed to both meat and eggs.

Because of almost all studies showing that children are more vulnerable than adults, WHO suppresses the acceptable value or Tolerable Daily Intake (TDI) with a value of 1-4 pg I-TEQ/(kg-day), while Environmental Protection Agency (EPA)-USA has a TDI of about $1 \mathrm{pg}$ I-TEQ/(kg-day) (Nouwen et al., 2001). The results of a dioxin dispersion modeling study in the Hangzhou region with a capacity of 800 tons MSW per day will give human dioxin exposure around 15.63 to $3.81 \mathrm{pg}$ I-TEQ /(kg day) at a distance of about $300 \mathrm{~m}$ from the chimney (Ma et al., 2012). This value is above the TDI required by WHO. The ambient air concentrations must have a value of $0.023 \mathrm{pg} \mathrm{TEQ} / \mathrm{Nm}^{3}$ to follow with the WHO TDI requirements. Studies in Taiwan show that ambient dioxin concentrations in coastal (urban) areas are 0.0039$0.0136 \mathrm{pg} \mathrm{TEQ} / \mathrm{Nm}^{3}$ and in mountainous regions have 0.0016-0.0029 pg TEQ/ $/ \mathrm{Nm}^{3}$ (Chandra et al., 2015). The air quality monitoring results in Hong Kong were $0.1 \mathrm{pg} \mathrm{TEQ} / \mathrm{m}^{3}$ in 1999 and $0.02 \mathrm{pg} \mathrm{TEQ} / \mathrm{m}^{3}$ in 2019 (https://www.aqhi.gov.hk). Some countries apply ambient air quality standards for dioxin differently. For example, in 1990, Connecticut-USA adopted standard $1 \mathrm{pg} \mathrm{TEQ} / \mathrm{m}^{3}$ (Rao and Brown, 1990). Japan applies annual standard $0.6 \mathrm{pg} \mathrm{TEQ} / \mathrm{m}^{3}$ [https://www.env.go.jp/en/air/aq/], Ontario Canada applies annual standard $0.1 \mathrm{pg} \mathrm{TEQ} / \mathrm{m}^{3}$ 24-hour. Thus, the TDI standard from WHO is still higher than the natural ambient air concentration. We have seen that the ambient air concentration due to the presence of MWPP in the study area is $0.04 \mathrm{pg} \mathrm{TEQ} / \mathrm{Nm}^{3}$. This concentration will result in dioxin exposure of $5.28 \mathrm{pg} \mathrm{I-TEQ/(kg-day)} \mathrm{for}$ adults and $6.95 \mathrm{pg}$ I-TEQ/(kg-day) for children, which is still above the WHO TDI limit of $4 \mathrm{pg}$ I- TEQ/(kgday). The strategy that can be done based on Equation 4 or Equation 7 is to reduce production capacity from 80 tons per day to 60 tons per day or increase the APC from $0.5 \mu \mathrm{g}$ TEQ/ton to $0.375 \mu \mathrm{g}$ TEQ/ton.

\section{CONCLUSION}

The development of atmospheric dioxin dispersion produced by MWPP and its impact on human health have been given in-depth in this paper. Dioxins disperse in the atmosphere in two phases. When it is close to the mouth of the chimney, the dioxin disperses in a gaseous form. While far away from the chimney, the absorption process occurs by dust particles so that the dioxin will form into a particulate phase. It is about 10 percent not absorbed by dust particles and then disperses in the form of a solid-gas phase. We use the nonGaussian solution of the advection-diffusion equation by considering the settling and deposition particle velocity. APS technology scenario is applied to simulate the dioxin dispersion from the MWPP. For the case of MWPP with a production capacity of 80 tons per day, it produces a concentration of $0.04 \mathrm{pg} T E Q / \mathrm{Nm}^{3}$ in a residential area within $200 \mathrm{~m}$ of the emission source. The resulting inhalation exposure was $5.28 \mathrm{pg}$ ITEQ/(kg-day) for adults and $6.95 \mathrm{pg} \mathrm{I-TEQ/(kg-day)} \mathrm{for} \mathrm{children.} \mathrm{The} \mathrm{strategy} \mathrm{is} \mathrm{taken} \mathrm{to} \mathrm{adjust} \mathrm{to} \mathrm{the} \mathrm{WHO}$ quality standard of $4 \mathrm{pg} \mathrm{I-TEQ/(kg-day)} \mathrm{reduces} \mathrm{the} \mathrm{production} \mathrm{capacity} \mathrm{to} 60$ tons per day, or increases the APC from $0.5 \mu \mathrm{g}$ TEQ/ton to $0.375 \mu \mathrm{g} \mathrm{TEQ} /$ ton. Calculation of emissions based on combustion processes produces ambient concentrations ten times less than calculations using emission factors. We apply to MWPP and show that the dioxin concentration is still below the threshold required by WHO. 


\section{ACKNOWLEDGMENT}

This research was funded by Badan Pengkajian dan Penerapan Teknologi (BPPT) for the 2019 fiscal year. We would thank Prof. Kardono for his valuable discussion.

\section{REFERENCES}

[USEPA] United States Environmental Protection Agency. 1999. Polychlorinated Dibenzo-p-dioxins and Related Compounds Update: Impact on Fish Advisories. Washington DC (US): USEPA.

[WHO] World Health Organization. 2000. Air Quality Guidelines for Europe. $2^{\text {nd }}$ ed. Copenhagen (DK): WHO.

Abad E, Martinez K, Caixach J, Rivera J. 2006. Polychlorinated dibenzo-p-dioxins, dibenzofurans and dioxin-like' PCBs in flue gas emissions from municipal waste management plants. Chemosphere. 63: 570-580.

Alimuddin, Tambunan AH, Machfud, Novianto A. 2018. Analysis of $\mathrm{CO}_{2}$ emissions from geothermal power plant ulubelu and its contribution to development of electricity generators in Lampung Province. JPSL. 9(2): 287-304.

Assegaf AJ. 2018. Gas dispersion modeling from the Chimney Power Plant Pasquil-Gaussian Model. JPSL. 8(3): 414-419.

Astrup T. 2008. Management of APC residues from W-t-E plants. An overview of management options and treatment methods. Rotterdam (NL): ISWA General Secretariat.

Briggs GA. 1973. Diffusion Estimation for Small Emissions. Preliminary Report. United States: N. p. doi: $10.2172 / 5118833$.

Carson JE, Moses H. 1969. The validity of several plume rise formulas. J Air Poll Cont Ass. 19(11): 862866.

Chandra SR, Lee WJ, Mutiara MPE, Mwangi JK, Wang LC, Lin NH, Chien GPC. 2015. Atmospheric deposition of polychlorinated dibenzo-p-dioxins and dibenzofurans at coastal and high mountain areas in Taiwan. Aerosol Air Qual Res. 15: 1390-1411.

Chao MR, Hu CW, Chen YL, Chien GPC, Lee WJ, Chang LW, Lee WS, Wu KY. 2004. Approaching gasparticle partitioning equilibrium of atmospheric PCDD/Fs with increasing distance from an incinerator: measurements and observations on modeling. Atmos Environ. 38: 1501-1510.

De Vivo B, Belkin H, Lima A. 2017. Environmental Geochemistry: Site Characterization, Data Analysis and Case Histories. Amsterdam (NL): Elsevier.

Dewi NWSP, June T, Yani M, Mujito. 2018. Estimating dust, $\mathrm{SO}_{2}$ and $\mathrm{NO}_{\mathrm{x}}$ dispersion from cement industry using gaussian model that integrated with screen3. JPSL. 8(2): 109-119.

Fiani E, Karl U, Tmlauf G, De Assuncao JV, Kaareka S, Fiedler H, Costner P, Weber R. 2013. Toolkit for Identification and Quantification of Releases of Dioxins, Furans and Other Unintentional POPS. Stockholm (SE): Stockholm Convention.

Hoogenboom LAP, Kramer HL, Jansen EHJM, Megeler MJB, Va Klaveren JD, Traag M, Kuiper WA, Konemen HA. 1995. Risk Assessment and Risk Management of Dioxin and PCBs in Food. Bilthoven (NL): RIVM.

Huang CJ, Chen KS, Lai YC, Wang LC, Chien GPC. 2011. Wet deposition of polychlorinated dibenzo-pdioxins/dibenzofuran in a rural area of Taiwan. Aerosol Air Qual Res. 11: 732-748.

Lali Z. 2018. Release of dioxins from solid waste burning and its impacts on urban human population- a review. J Pollut Eff Cont. 6: 1-6. doi: 10.4172/2375-4397.1000215.

Lee CC, Lin SD. 2007. Handbook of Environmental Engineering Calculations. 2nd ed. New York (US): McGraw-Hill Companies. 
Lee KL, Lee WJ, Mwangi JK, Wang LC, Gao X, Chien GPC. 2016. Atmospheric PM2.5 and depositions of polychlorinated dibenzo-p-dioxins and dibenzofurans in Kaohsiung Area, Southern Taiwan. Aerosol Air Qual Res. 16: 1775-1791.

Lohman K, Seigneur C. 2001. Atmospheric fate and transport of dioxin: local impact. Chemosphere. 45: 161-171.

Vilavert L, Nadal M, Schuhmacher M, Domingo JL. 2012. Long-term monitoring of dioxins and furans near a municipal solid waste incinerator: human health risks. Waste Management and Research. 30(9): 908-916.

Ma XJ, Jiang XG, Jin YQ, Liu HM, Li XD, Chen T, Yan JH. 2012. Dispersion modeling and health risk assessment of dioxin emissions from a municipal solid waste incinerator in Hangzhou, China. $J$ Zhejiang Univ-Sci A (Appl Phys dan Eng). 13(1): 69-78.

Mc Kay G. 2002. Dioxin characterisation, formation and minimisation during municipal solid waste (MSW) incinerator: review. Chem Eng Journal. 86: 343-368.

Mohan SM. 2016. An overview of particulate dry deposition: measuring methods, deposition velocity and controlling factors. Int J Environ Sci Technol. 13: 387-402. doi: 10.1007/s13762-015-0898-7.

Nouwen J, Cornelis R, Fre RD, Wever M, Vuane P, Mensik C, Patyn J, Vershane L, Hooge R, Collier M, Schoeter G, Van Cleuvenbergen R, Geuzen P. 2001. Health risk asssessment of dioxin emission from municipal waste incinerator: the neerlandquarter, Chemosphere. 43: 909-923.

Nzihou A, Themelis NJ, Kemiha M, Benhamou Y. 2012. Dioxin emissions from municipal solid waste incinerators (MSWIs) in France. Waste Management. 32(12): 2273-2277.

Okubo M, Kuwahara K. 2019. New Technologies for Emission Control in Marine Diesel Engines. Oxford (GB): Butterworth-Heinemann.

Olie K, Vermeulen PL, Hutzinger O. 1977. Chlorodibenzo-p-dioxins and chlorodibenzofurans are trace components of fly ash and flue gas of some municipal incinerators in the Netherlands. Chemosphere. 9(8): 501-522.

Rao HR, Brown DR. 1990. Connecticut's dioxin ambient air quality standard. Risk Analysis. 10(4): 597-603.

Ryan P. 1993. Review of mathematical models for health risk assessment IV, intermedia chemical trasport. Environ Software. 8: 157-172.

Seinfield JH, Pandis SN. 2016. Atmospheric Chemistry and Physics: From Air Pollution to Climate Change. New York (US): Wiley and Son.

Stockie JM. 2011. The mathematics of atmospheric dispersion modeling. SIAM Review. 53(2): 349-472.

Sulaiman A, Sadly M. 2014. Integration of smoke dispersion modeling with earth's surface image, international conference on advanced computer science and information systems. Proc IEEE Indonesia section. 428-432. doi: 10.1109/ICACSIS.2014.7065886.

Thohiroh NA, Mardiati R. 2017. Desain Pembangkit Listrik Tenaga Sampah (PLTSa) menggunakan teknologi pembakaran yang fisibel studi kasus TPST Bantargebang, SENTER. 212-224.

Ujam AJ, Eboh F. 2012. Flue gas analysis of a small-scale municipal solid waste-fired steam generator. Int $J$ of Compt Eng Res. 2(8): 2250-3005.

Warlina L. 2015. A dynamic model of the pollution impact of dioxin/furan on the environment, society and economy. WIT Transactions on Ecology and The Environment. 198: 403-415.

Warlina L, Noor E, Akhmad F, Tarumingkeng RC, Sutjhahjo SH. 2008. Estimasi emisi dioksin/furan dan faktor-faktor yang memperngaruhi konsentrasi emisi ke udara yang berasal dari industri logam. Jurnal Matematika, Sains dan Teknologi. 9(1): 11-20.

Winanti WS. 2018. Teknologi pembangkit listrik tenaga sampah (PLTSa). Prosiding Seminar Nasional dan Konsultasi Teknologi Lingkungan. 65-72.

Wu YL, Lin LF, Shih SI, Yu KM, Hsieh LT, Wang LC, Chien GPC. 2009. Atmospheric deposition of polychlorinated dibenzo- $p$-dioxins and dibenzofurans on the soils in the vicinity of municipal solid waste incinerators. J Environ Sci Heal Part A. 44(13): 1327-1334. doi: 10.1080/10934520903213020. 
Xu MX, Yan JH, Lu SY, Li XD, Chen T, Ni MJ, Dai HF, Wang F, Cen KF. 2009. Concentrations, profiles and sources of atmospheric PCDD/Fs near a municipal solid waste incinerator in Eastern China. Envir Sci and Technology. 43(4): 1023-1029.

Zhu J, Tang H, Xing J, Lee WJ, Yan P, Cui K. 2017. Atmospheric deposition of polychlorinated dibenzo-pdioxins and dibenzofurans in two cities of Southern China. Aerosol Air Qual Res. 17: 1798-1810. 